\title{
From Mendel to genomics, plant breeding milestones: a review
}

\author{
Aluízio Borém*1; Elcio Perpétuo Guimarães²; Luiz Carlos Federizzi ${ }^{3}$ and José Francisco Ferraz \\ de Toledo ${ }^{4}$ \\ ${ }^{1}$ Universidade Federal de Viçosa, Departamento de Fitotecnia, CEP 36.570-000, Viçosa, MG, Brazil; ${ }^{2}$ Senior Officer for \\ Cereals/Crops Breeding at FAO, Rome, Italy. E-mail: guimaraes@fao.org; ${ }^{3}$ Universidade Federal do Rio Grande do Sul, \\ Faculdade de Agronomia, Av. Bento Gonçalves, 7712, CEP 91.501-970, Porto Alegre, RS, Brazil; ${ }^{4}$ Embrapa Soja, Caixa \\ Postal 231, CEP 86.001-970, Londrina, PR, Brazil. (* Corresponding Author. E-mail: borem@ufv.br)
}

\begin{abstract}
Plant breeding has evolved from an intuitive strategy of choosing the best plants in the field to an exciting science of combining genes to improve desirable traits. Our objective with this paper is to review some of the most important discoveries and developments that had an impact on plant breeding. First, we present background information and then the milestones themselves. The topics were grouped into chapters to facilitate comprehension of their contribution to plant breeding. They are discussed within each chapter in a plant-breeding-oriented chronological way. When applicable, the definition, importance and evaluation of the topics are presented.
\end{abstract}

KEY WORDS: Genetics history, plant improvement, heredity, biotechnology, retrospective.

\section{INTRODUCTION}

Plant breeding is the science and the art of improving plants to make them better suited to humankind. As an art, it depends on the intuition and past experiences of each individual breeder. As a science, it depends on the theoretical and practical knowledge in the field of genetics, statistics, agronomy, plant pathology, and many others. Above all, plant breeding has fascinated, challenged and gathered many scientists, as well as contributed to prevent starvation in many countries.

Many people believe plant breeding is a postMendelian science. However, plant breeding in its rudimentary form started with farming about 12,000 years ago, in the form of selection of more suitable plants to man's needs throughout history. There are no records, but certainly one of the most important event was the domestication of crop and horticultural plants, such as wheat, barley, maize and apples. It is breathtaking to imagine that man's ancestors were able to understand that, through careful selection and replanting, they could change the nature of food plants in the directions they wished. There is some evidence that early-time biologists were crossing corn plants and producing hybrids well before Mendel's work.

The onset of a scientific approach to plant breeding was perhaps the discovery of the cell and the role of sex reproduction in living organisms. It was Robert Hooke's discovery of cells in a piece of cork in 1665 that opened the door to many discoveries and inventions in biology and, especially, in genetics, although microorganisms had already been used for many years in the production of wine and bread. About 10 years later, Anton van Leeuwenhoek built a microscope with a $270 \mathrm{X}$ amplification power, which allowed him to see microorganisms for the first time. The microscope opened the window to a new world, previously invisible to man. About 170 years later, Matthias Schleiden and Theodore Schwann presented the theory that all living organisms are constituted by cells.

It is not clear how much of intentional hybridization, in order to provide new genotypes for selection, was performed before the scientific studies of sex role in plants started. On August 25, 1694, R.J. Camerarius published a paper in letter format entitled "De sex plantarum epistola". Others may argue that plant breeding dates from the time of Thomas Fairchild's first artificial plant hybrid production (carnation $\mathrm{x}$ sweet william) in England in 1717, and Mather's cotton hybrid (squash x gourd) in America around the same time. In 1760, J.G. Kolreuter carried out the first scientific experiment in plant hybridization; in 1823 , Thomas A. Knight used hybridization to improve crops and, by 1839, Carl F. von Gärtner had performed more than 1,300 different crosses. J.G. Kölreuter (17611766) published his plant breeding work in Germany describing over 100 experiments with artificial hybridization, especially crosses, backcrosses, and $\mathrm{F}_{2}$ generations between tobacco species. During the 19th century, practical plant breeding started as business and, in 1819, Patrick Shireff in Scotland selected the first varieties of wheat using pure line selection. In France, Louis Vilmorin improved varieties of wheat and sugar beet using progeny tests. 
As knowledge evolved, new issues such as why offspring tend to resemble their parents called the attention of some scientists, but it was only at the end of the 19th century that the monk Gregor Mendel, working in Brno in the Czech Republic, unveiled the secrets of heredity.

Genetic knowledge to support plant breeding has advanced rapidly in the 20th century. By placing together a few more parts of the puzzle emerging from the findings of this new exciting science, scientists in the first half of the 1900's were able to conclude that something inside the cell was responsible for heredity. After the addition of dyes for visualization of cells under the microscope, some structures that were stained in a distinct way were identified and named chromosomes. It was eventually learnt that these structures, the chromosomes, carried the genes that coded for the diversity of life. Although the genes determined human stature, eye color, hair color, and other traits, they could not be seen. However, their protein products could, and in 1941, George Beadle and Edward Tatum established a theory called "one gene, one enzyme", which answered a question that had persisted in the scientific community for many years: how genes provide instructions for building proteins. In 1944, Oswald Avery identified the DNA (deoxyribonucleic acid) as the gene's fundamental material. From this starting point, several research groups have devoted their time to study the DNA, and its chemical composition was quickly elucidated. The DNA is a molecule made of sugar, phosphate and four nitrogen bases i.e. adenine, cytosine, guanine and thymine (identified by the initials A, C, G, and $\mathrm{T})$. Later, scientists realized that the four nitrogen bases, also known as nucleotides, were the alphabet of the genetic code.

The year of 1953 became a landmark for genetics with the discovery of the double-helix DNA structure by two scientists working at Cambridge University in England: James Watson and Francis Crick, an American and a British scientist, respectively. Their work revolutionized genetics and accelerated the discoveries of the fine DNA structure. The DNA capability to code for all the biological processes of living organisms relies in the genetic alphabet (A, C, $\mathrm{G}$ and $\mathrm{T}$ ) which is written in the chromosomes. Genes differ in size (number of letters or nucleotides) and sequence (order of the nucleotides). For instance, a gene can have the following sequence: ATGCCGTTAGACTGAAA. However, one question remained: how the sequence of letter translated into proteins and traits.

Cracking the genetic code challenged geneticists.
How could only four nucleotides code for the 20 different amino acids that constitute the thousands of existent proteins found in living organisms? It was only in 1967 that Marshall Niremberg and Har Gobind Khorana deciphered the genetic code. They concluded that the DNA was translated by groups of three nucleotides (or bases), later called codons. As there are four nucleotides (A, T, C and G), there would be 64 different ways to arrange them into different codons. Taking into consideration that there are only 20 amino acids, the 64 different codons were more than enough to code for each of them.

\section{GENETIC VARIABILITY AND EVOLUTION}

\section{Genetic variability and centers of origin}

The great navigators of the 15 th century always brought home seeds of crops that were an important source of food or fiber. This idea was further developed to the introduction of new plants types, which carried genes of interest. Plant explorers were sent to different parts of the world to look for variability, the raw material of plant breeding. One of the most important explorers was a Russian named Nikolai Ivanovich Vavilov, who traveled extensively and identified eight areas in the world as centers of diversity of several crop species. He distinguished them between primary centers, which corresponded to the maximum occurring diversity suggesting the place where the crop was first domesticated, and secondary centers, which developed from plant types migrating from the primary center. Vavilov considered these centers of diversity as centers of origin. He also demonstrated the existence of parallelism in variability among related species (the law of homologous series in heritable variation). The relevance of this law is that plant explorers could, to a certain extent, predict the forms not yet described, similar to what molecular geneticists are doing today based on sinteny between related species.

Presently, many germplasm banks around the world collect and protect the available genetic variability, the raw material of evolution and commercial breeding to preserve the future of new generations.

\section{Darwin's theory on natural selection and neo- Darwinism synthetic theory of evolution}

Darwin's theory was that plants and animals vary in their traits, and that the variation is often heritable. Bestadapted individuals would survive the natural selection and would leave more descendents to the following generation, and since selection continues over 
generations, evolution was likely to take place. Because the mechanism of heredity was not known in that time, Darwin's ideas were not well accepted; and in the early decades of the 20th century, with the discovery of Mendel's work along with Johannsen's work, many biologists thought the Darwinism was dead. In the 1930s, the work of Fisher, Wright, Haldane, Dobzhansky, Huxley, Mayr, Simpson and Stebbins in different fields of mathematics and population genetic brought about an integration of the Mendelian genetics and Darwin's evolutionary theory. These works demonstrated that the Darwinian mechanism - natural selection- in Mendelian populations was enough to explain the evolutionary process observed in nature. The full depth and importance of Darwin's work on the adaptation and evolution of animals and plants was then clearly understood.

\section{Cytogenetics}

Cytogenetics aided not only the development of plant genetics but also the understanding of species relationships. Along with polyploidization, cytogenetics played an important role in plant breeding efforts after the Second World War. The integration of cytogenetics to applied plant breeding was first done by E.R. Sears, who worked with wheat and by C.M. Rick, who worked with tomatoes. They demonstrated the possibility of transferring genes and chromosomes from alien to crop species, contributing to the use of cytogenetics in the evolutionary study of plant species.

Cytogeneticists introduced a new genetic variation from many relatives in species of agronomic interest. This has been especially important in disease resistance breeding. While introducing race specific resistance genes from alien sources, breeders develop varieties with a more durable resistance.

The best kwon introgression of alien germplasm accomplished by cytogenetics/plant breeding was the short arm of chromosome $1 \mathrm{R}$ from rye, which was substituted for chromosome 1B of wheat. The introduction of the 1BL-1RS translocation in wheat has been traced back to the work done in the 1920's in Germany. The rye segment carried an array of useful disease resistance genes for leaf rust, yellow rust, stem rust and for mildew resistance. In other crops such as corn, translocations and chromosome introgressions were also important.

\section{Mutagenesis}

The pioneering experiments by Muller (1927) showed that it is possible to alter the effect of genes. This new possibility was looked upon with great optimism. However, after a few decades of research skepticism resulted from the disappointing experiments in generating useful mutations.

After World War II funds became available for peaceful uses of atomic energy and many researchers in both developed and developing countries embarked on the fashionable technology of using radiation and radioactive isotopes for inducing mutations, often not paying attention to the rather modest results obtained between 1930 and 1945. In the following 20 years research mutation facilities were built around the world funded by the United Nations Atomic Commission. The International Atomic Energy Agency (http://www.iaea.int) affiliated with the United Nations had supported the development of mutant varieties.

Mutation breeding has now a more restricted but better-defined place among the methods of applied genetics. In addition to the use of induced mutations in crop improvement, there is now a most valuable use in fundamental genetics and plant physiology.

\section{PLANT BREEDING THEORY AND RELATED ISSUES}

\section{Mendel's laws}

In the middle of the 19th century, the monk Gregor J. Mendel, working in Brno, in the Czech Republic, studied the genetic ratios of segregation, the first step to understand the secrets of heredity. Mendel noticed that traits of the garden pea plant, such as the flower color, plant height, and seed shape, were consistently transferred from parents to offspring. An inquisitive mind caused Mendel to make hundreds of crosses with different pea plants over many years. In recording the segregation of traits from thousands of plants, he discovered that they segregated in predictable ratios, season after season, indicating that the units of heredity were passed from generation to generation. These discoveries were presented in forums in the mid 1800's and compiled in Mendel's "Experiments in Plant Hybridization" published in 1865. These were key discoveries to the emerging sciences of heredity, genetics and ultimately to plant breeding. Notwithstanding, Mendel's work was largely ignored during his lifetime. In fact, his research was virtually lost for 30 years, until it was independently discovered by three scientists, providing geneticists and breeders with a solid basis for handling trait heritability in substitution to some vague mystical effects. 


\section{Pure line theory}

The experiences of plant breeders played their part in developing breeding methods, but it remained for Johannsen to place the individual-plant method of selection on a firm scientific basis. In 1903 and 1906 he studied field beans, a good choice because it is self-pollinated and contains traits that can be easily measured. He hoped to control heredity by applying Galton's law of regression, i.e. that the progeny of parents above or below the average tend to revert to average type. By selecting extreme individuals every generation, Johannsen observed improvement only in the first generation. From the second generation onwards all observed variability was due to the environment and was not passed to descendents. Johannsen's findings had a large effect on plant breeding, as he was the first to separate genotype from phenotype. He defined as pure-lined any individual obtained by continuously selfing the progeny from a cross between homozygous individuals.

\section{Hardy-Weinberg equilibrium}

In 1908, Hardy in England and Weinberg in Germany independently demonstrated that in a large random mating population both gene frequencies and genotypic frequencies remain constant from generation to generation in the absence of mutation, migration, and selection. Breeding of cross pollinated species has since then been strongly based on the principles of the HardyWeinberg law.

\section{Genetic improvement procedures/ breeding methods}

The genetic improvement procedures or breeding methods that are commonly used today were developed even before Mendel's discovery of genetics (Olsson, 1986). They included mass selection, pedigree and bulk breeding. Later, in the first part of the $20^{\text {th }}$ century backcross and recurrent selection were put forward. Other methods, such as single seed descent, were adopted much later.

Selection of the best ear of corn or wheat for planting the following season was a practice used by farmers since the end of $17^{\text {th }}$ century. However, the first scientific wheat-breeding program started in 1898, by the Swedish Seed Association at Svalof, under Nilsson-Ehle. He used to hybridize wheat varieties to increase the genetic variability. Because of the large number of crosses, generations and plants involved each year, he invented the bulk method.

Louis de Vilmorin working in the $19^{\text {th }}$ century in France was the first one to understand the effects of plant selection. Vilmorin developed the concept of plant selection with progeny test, which became known as the "Principle of Vilmorin". With his method he was able to carefully select beets based on their size, shape, and sugar content.

Although the origin of the pedigree method is unknown, its first description can be attributed to Newman (1912), who reported that until 1891, mass selection with self-pollination was predominantly used to improve self-pollinating species. The term pedigree selection was used when single-plant selection was performed to isolate pure lines in heterogeneous landraces. The pedigree method is still widely used with both self- and cross-pollinated species during population inbreeding.

Harlan and Pope (1922) emphasized the value of backcrossing for genetic improvement of crop varieties, observing that it had been used for many years in animal breeding to fix traits. Since then, backcross breeding has been used to improve varieties for individual traits, becoming a common method in some breeding programs. At the University of California a series of small grain varieties was developed by backcrossing. The Atlas barley varieties were developed in the 1920 and 1930 using this method. It has lost its popularity among plant breeders in the second half of the $20^{\text {th }}$ century. With the event of biotechnology new traits are coming to the market through using backcrossing to transfer them into elite lines. Thus, it is expected that backcross breeding will continue to play an important role in plant improvement.

Goulden (1939) was the first to propose the concept of the single seed descent method (SSD). It did not catch the attention of many plant breeders until 1966 when Brim elegantly described it. Since then, SSD has become one of the most popular breeding method for inbreeding segregating populations in self- and cross-pollinated species.

Corn breeding methods have evolved over time with open-pollinated varieties, double-cross hybrid varieties and single-cross hybrid varieties, each one being popular in turns. H.K. Hayes and R.J. Garber at Minnesota, in 1919, and E.M. East and D.F. Jones, in 1920, independently suggested the concept of recurrent selection. Richey suggested the convergent breeding to increase vigor by recurrent cycles of selection. However, it was Hull (1945) who coined the term recurrent selection, which was immediately adopted. In 1949, F.E. Comstock, H.F. Robinson and P.H. Harvey proposed the use of reciprocal recurrent selection. Recurrent selection has been currently used 
in both cross and self-pollinated species, although it was developed with corn, a cross-pollinated grass. H.K. Hayes and R.J. Garber described the method for obtaining synthetic varieties in 1919.

\section{Ideotype breeding}

The idea that plant physiology could contribute to plant improvement by helping understand physiological events drove many research institutions to devote time, resources and personnel to this area. The first major emphasis in breeding for ideotype was reported by Donald, an Australian biologist. In the U.S., Adams at Michigan State University and Rasmusson at the University of Minnesota applied the ideotype concept in common bean and barley, respectively, in the development of new varieties.

Ideotype breeding may not have delivered all that it promised at first, but there is no question of its importance in shaping the way breeders handle their programs. With the idea of pursuing a model, plant breeders were compelled to organize their thoughts and goals. Ideotype breeding also prompted breeders to introgress exotic germplasm in the breeding populations, expanding the genetic diversity used in varietal development.

\section{Gene for gene hypothesis}

Postulated by H.H. Flor (1956), it introduced the concept that both host and parasite genetics played a role in determining whether or not a resistance reaction would be observed. Flor put forward the concept that the expression of resistance by the host was dominant while conversely the expression of avirulence by the parasite was dominant. This concept was carried forward by others, namely Clayton Person, in order to advance a theory that there was a single gene in the host that interacted with a single gene in the parasite. This theory was put forward at about the same time that the "one gene one protein" idea was being discussed by biochemists. Flor used this basic understanding when he formulated the "Gene-for-gene concept". Flor's tenet pointed out that basic host - parasite interactions are regulated by the genetic components of both the host and the parasite. Though that concept has been challenged by some, it is useful in understanding plant diseases. Flor's concept is still valid today and explains many hostpathogen interactions. A lot of research has been done in plant pathology since Flor's work and it is believed that about $25 \%$ of the plant breeding efforts in many crops have been devoted to the development of disease resistant varieties.

\section{High yield and stability breeding}

High yielding and stable cultivars are the main goal of any modern breeding program. Many high yielding modern cultivars are not commercially successful due to poor stability, while many highly stable cultivars do not provide adequate economic return. Breeding high yielding and stable cultivars is a major challenge facing breeders. Yield is essentially a complex quantitative trait controlled by numerous genes of individual small effects that are highly influenced by the environment. Stability can be achieved through the introduction of genes expressing resistance to diseases and insects, drought tolerance, nutrient extraction efficiency and many other factors. Breeding for stability also prompted breeders to introgress exotic germplasm in the breeding populations, expanding the genetic diversity used in varietal development. Further, it may help to preserve the environment for the future generations by reducing the use of agronomic inputs and allowing organic agriculture to develop.

\section{Heterosis/hybrid vigor}

Although many plant breeders in the 18th century observed hybrid vigor, a clear understanding of the effects of self-fertilization in cross-pollinated crops and of the effects of crossing self-pollinated plants was obtained only as a result of later genetic research. In 1876, James Beal, at Michigan Agricultural College carried out the first controlled crosses of corn to increase yield. George H. Shull started inbreeding open-pollinated corn at the Station for Experimental Evaluation, Cold Spring Harbor, NY. East and Hayes $(1908,1909)$ pointed out the value of hybrid vigor both in evolution and in plant breeding. Shull (1908, $1909,1910)$ suggested the term heterosis in the following words: "To avoid the implication that all the genotypic differences which stimulate cell division, growth and other physiological causes are Mendelian in their inheritance and also to gain brevity of expression, I suggest that instead of the phrases 'stimulus of heterozygosis', 'heterozygotic stimulation', the word heterosis be adopted." The studies of Shull and East were independently conducted at the same time at closely located sites. They reported their findings in the same year (1908), but the correct interpretation of the phenomenon of inbreeding and heterosis was given by Shull.

Although other scientists were studying heterosis at the same time as Shull, his clearness and elegance drew the world's attention to hybrid vigor. Shull was studying plant height, number of kernel, kernel rows 
per ear and yield of inbred lines when he published his milestone paper "The composition of a field of maize" in the proceedings of the American Breeders Association in 1908.

The original concept to commercially exploit heterosis was the production of single-cross hybrids, but the costs of seed production initially limited its usefulness. This limitation was overcome with Jones's (1918) suggestion that double-cross hybrids can be produced from two single-cross hybrids to reduce costs of seed production and, consequently, doublecross hybrids became rapidly accepted worldwide. Since 1960, single-cross hybrids have been replacing double-cross hybrids in many places in the World.

\section{Statistical principles and experimental designs}

Ronald Fisher, considered the father of modern statistics, worked at the Rothamsted Agricultural Experiment Station as a biologist and made many contributions to both statistics and genetics. He introduced the concept of randomization and analysis of variance procedures, now used throughout all biology. He also introduced the concept of likelihood and gave a new definition to statistics. Its purpose was the reduction of data and he identified three fundamental problems. The contributions Fisher made included the development of methods suitable for small samples, the discovery of the precise distributions of many sample statistics and the invention of analysis of variance. He introduced the term maximum likelihood and studied hypothesis testing.

Statistics arose in synchrony with ideas about quantitative genetics and gave breeders ways to deal with measurements and scores of quantitative traits. Statistics was essential to the formulation of theories about quantitative genetics, and to practical application of those theories.

\section{Quantitative genetics}

Because single genes explain only a limited number of traits that mattered to breeders, quantitative genetics came about to give rational ways to deal with inheritance of quantitative traits. The boom of quantitative genetics started around the 50's, when Jenkins' work about the diallel designs was developed. In the 60 's, quantitative genetics was so mainstream that in just about all scientific meetings it would be main theme. Quantitative genetics has helped to understand and account for $\mathrm{G} \times \mathrm{E}$, adaptability and stability as well as in the interpretation of data collected in breeding experiments.

One of the most important contributions of quantitative genetics to plant breeding was the partitioning of the expected mean square into the covariance between relatives. The paper by Cockerham (1961) published in the Crop Science journal was paramount in connecting statistics (sources of variation and variance components) to genetics (covariance among relatives). The following work of Falconer in Scotland, Mather and Jinks in England, Eberhardt and Comstock in the USA and Vencovsky in Brazil, among others, further developed this important branch of the genetic science, providing many handy tools for unraveling the intricate genetic control of quantitative traits.

\section{Green revolution}

The green revolution involved the simultaneous development of new varieties of food plants and altered agricultural practices that greatly increased crop yields. It became a worldwide agricultural movement which began in Mexico in 1944, when the Rockefeller foundation and the Mexican government established a plant-breeding station with a goal of boosting grain yields. Norman Borlaug, a plant breeder from the University of Minnesota headed the project. His research lead to high-yielding wheat plants. Later, Borlaug won the Nobel Peace Prize for his work that reduced famine in Asia and other regions.

Borlaug's wheat varieties were successful when grown in many areas of Asia and Africa. In India, wheat production increased four times in 20 years (from 12 million tons in 1966 to 47 million tons in 1986). The successes in Mexico with wheat led to the establishment of other breeding programs emphasizing short stature plants. In fact the green revolution subsequently occurred Worldwide in many crops including rice, sorghum, maize, cassava, and beans.

Borlaug basis for the Green Revolution was the use of short "semi-dwarf" wheat germplasm in his breeding program. The semi-dwarf genes increased the harvest index in the new varieties, making them yield significantly more that the conventional varieties.

\section{Breeder's intellectual property}

The interest of the industry in breeding self pollinated crops became more evident after the Plant Variety Protection Act (PVPA) was enacted in December 1970 and amended in 1994. This provided legal intellectual property rights protection to developers of new varieties of plants that are sexually reproduced (by seed) or are tuber-propagated. Bacteria and fungi are excluded. The PVPA is administered by the United 
States Department of Agriculture. A Certificate of Protection is awarded to an owner of a variety after an examination shows that it is new, distinct from other varieties, and genetically uniform and stable through successive generations.

The term of protection is 20 years for most crops and 25 years for trees, shrubs, and vines. The owner of a U.S. protected variety has exclusive rights to multiply and market the seed of that variety. Some scientists still believe that the breeder's intellectual property also had a negative impact in plant breeding, reducing the exchange of information and germplasm among breeders and companies.

The breeder's intellectual property has had a major impact in plant breeding since 1990 and it is expected to have an even larger impact in the future, especially with the biotech traits introgressed in the new varieties. In Brazil, the intellectual property issue has also been dealt with since the Paris Convention in 1835. But it was only in 1994, when the Brazilian Congress ratified the "Agreement on Trade Related Aspects of Intellectual Property Rights" (TRIPS) of GATT that the issue was discussed for legislation purposes. In January 1995 and in April 1997, the Brazilian Biosafety legislation and the Variety Protection Law were respectively approved.

\section{BIOTECHNOLOGY IN PLANT BREEDING}

\section{Discovery of the DNA structure}

The Watson-Crick hypothesis provided chemical explanation and high accuracy to Mendelian genetics and led to the development of molecular biology, which allows breeders to know intimate details of genes and to manipulate them. At the moment, however, this science is at about the same stage as when Mendelian genetics was established but quantitative genetics had not been developed. Molecular biology gives too much detail and too much precision as far as breeders are concerned at this time. At this time geneticists/breeders are trying to develop something akin to quantitative genetics to deal with the masses of information they have accumulated on genes, gene products, gene regulation and pathways of action and interaction.

\section{Biotechnology}

Biotechnology is the application of biological research techniques to the development of products or processes, using biological systems, living organisms, or derivatives thereof. It can also be understood as a range of different molecular technologies such as gene manipulation and gene transfer, DNA taping and cloning of microorganisms, plants and animals. Under biotechnology is also tissue culture, genomics and bioinformatics.

\section{Tissue culture}

One of the major breakthrough in tissue culture occurred when Murashige-Skoog developed the MS media in 1962 containing nutrition factors that allowed the in vitro growth of many tissue types.

Tissue culture encompasses many techniques that can be applied to plant breeding, such as embryo rescue, anther culture, micropropagation, indexation, in vitro selection, and somaclonal variation. Anther culture is important especially in crosses between individuals from different species. In those cases, it is frequently necessary to rescue the embryo in the developing seed to obtain the interspecific hybrid.

Anther culture has been widely used in the breeding of wheat, barley, corn and many other species. It provides a fast mean to reach homozygosity after crossing two parents. While using conventional breeding methods such pedigree, bulk and SSD may take from 4 up to 7 or more years to reach homozygosity, with anther culture it is possible to substantially shorten this period. Some varieties have been developed using anther culture in different countries around the World.

Tissue culture has also been important to provide means for the regeneration of whole individual plants in gene transformation systems such as biolistic or Agrobacterium mediated transformation. Therefore, tissue culture is expected to play an even more important role in cultivar development in the future.

\section{Molecular markers}

Molecular markers are DNA fragments that may be used as a fingerprint in the identification or characterization of individuals. These markers have become an increasingly helpful tool in genetic research, and in biotechnology applications. The basic premise behind molecular markers is that there is a natural genetic variation in individuals, and many genetic sequences are polymorphic, meaning that they differ between individuals. Molecular markers seek to exploit this variation to identify individuals, traits, or genes based on genetic differences. Two of the most common molecular markers used in plant breeding are: Restriction Fragment Length Polymorphism (RFLP) and Randomly Amplified Polymorphic DNA (RAPD). In recent years more and more molecular markers have become available. 
Some of them are STR (Short Tandem Repeats or Microsatellites), STS (Sequence Tagged Sites), Expressed Sequence Tags (EST), DNA Chips, SNP (Single Nucleotide Polymorphism or point mutations), AFLP (Amplified Fragment Length Polymorphism), and SCAR (Sequence characterized Amplified Regions). They have been used to establish a link between genes and traits, and to determine the location of genes in the genome and in marker assisted selection. With the detailed maps and probes for genes of known function, it has become possible to discover close linkages of a molecular marker with a trait of interest. This information has been used to move genes from one genetic background to another.

\section{Gene transformation}

Genetic transformation may be regarded as a century event in genetics and in plant breeding, in the sense that creating transgenic organisms enables breeders to develop varieties never thought before (despite the utility of and the great excitement and/or fear about Bt maize/cotton and RR soybeans). Such single gene changes can be very nice additions, but single gene changes are not fundamental to making improved varieties. On the other hand, genetic transformation is a very powerful tool for learning about gene functions. Transgenic breeding creates "artefactual" variants de novo and transgress the barrier between species. It will help in the real task for breeders: to manipulate the regulation, interactions and pathways of operation of many genes at once in order to make a well-balance organism. Molecular plant breeding for the construction of organisms that make entirely new products such as pharmaceuticals or chemicals would not be possible without genetic transformation.

\section{Genomics}

In recent years, technological advances in molecular biology and bioinformatics have consolidated genomics, putting genetics into a new age. Genomics is a science that uses molecular characterization, transcript profiling and cloning of whole genomes to understand the structure, function and evolution of genes as well as to answer fundamental biological questions. It is a brand new science that promises to revolutionize plant breeding and genetics itself. Probably, the main contribution of genomics to plant breeding will be the knowledge generated, which will allow breeders to accomplish their goals in a much faster and predictable manner. For example, genomics will reveal the underlying function of genes, placing plant models (ideotypes) within reach of plant breeders without the linkage drag. When genetics came about at the beginning of the $20^{\text {th }}$ century, it shed light in the breeding work done by practical plant breeders. Genomics is shedding new light into plant breeding.

The Arabidopsis genome and rice genomes, which are models for dicots and monocots respectively, were sequenced in 2000 and April 2002. The sequencing of other crop genomes will come at a faster rate than previously thought. The knowledge of model genome sequences will allow scientists to reveal genetic principles putting the science of genetics into a new perspective. For example, the sequence of the $A$. thaliana genome has revealed the genes and principles of flowering. Scientists have then manipulated yellow poplar (Populus trichopulus), developing varieties of this tree that blossom when they are one year old, much sooner that other conventional varieties (http:/ /www.fsl.orst.edu/tgerc/index.htm).

The discovery of genes of agronomic relevance for transformation is another application of the genome sequencing projects. Scientists will be able to scan the genome sequence searching for functional genes to be used as raw material in transgenesis.

Identification of genes at the molecular level is also useful in plant breeding because it allows screening those parents carrying desirable alleles and identification of perfect markers for traits that can be used in effective marker assisted selection. Institutions with sequence databases, EST and good germplasm access are expected to realize most of the benefits from genomics.

\section{Bioinformatics}

Bioinformatics is understood as the use and organization of the biological information. In particular, it concerns organizing bio-molecular databases (particularly DNA sequences), using computers for data analysis, and integrating information from diverse biological sources. Raw DNA sequences, gene expression data or other biological data is of little use until it has been appropriately analyzed and understood. Bioinformatics is a tool for that.

The biological research produces more than 250,000 papers annually, which in general summarizes large data sets collected in experiments. The science of biotechnology is generating a much larger amount of data, especially in the sequencing projects. The complete rice genome generated millions of millions of nucleotide sequences that were added to GenBank and other databases 24 hours a day. Bioinformatics is the only realistic way to study and assess all generated information. 


\section{FUTURE PERSPECTIVES}

Plant breeding is a one-century old science. Plant breeders have modified crop plants by selection mainly by using techniques discovered in the first 50 years post Mendel's law rediscovery. With the advent of biotechnology as a new tool available to plant breeders, genetic improvement is expected to continue to occur at a much faster and accurate pace. The events of genetic transformation and use of genes from unrelated species in breeding programs, will most likely bring substantial changes and progress. While progress has been made in developing improved varieties with conventional genetics, many new opportunities remain to be explored. With a more in depth insight into genetic enhancement, plant breeding efficiency is expected to increase during the $21^{\text {st }}$ century. Opportunities for plant improvement are thought to be greater today than when most of the genetic diversity had not been exploited, about a century ago.

\section{RESUMO}

\section{De Mendel a genômica, progressos importantes no melhoramento de plantas: uma revisão}

O melhoramento de plantas evoluiu de uma estratégia intuitiva de escolha das melhores plantas no campo a uma estimulante ciência de combinar genes para melhorar características desejadas. Nosso objetivo com este trabalho é revisar, para a comunidade científica, especialmente os melhoristas, algumas das descobertas mais importantes e que causaram impacto no melhoramento de plantas. Inicialmente apresentamos algumas informações básicas e em seguida discutimos os eventos marcantes. Os tópicos foram agrupados em capítulos, para facilitar a compreensão de suas contribuições ao melhoramento de plantas, e discutidos dentro de cada um colocando-os em forma cronológica e orientados ao melhoramento de plantas. A definição, a importância e a avaliação dos tópicos foi apresentada quando julgamos pertinente a melhor compreesão dos eventos.

\section{REFERENCES}

Bhat, S.R. and Srinivasan. 2002 Molecular and genetic analyses of transgenic plants: considerations and approaches. Nature. 349:726.

Brim, C.A. 1966. A modified pedigree method of selection in soybeans. Crop Science. 6:220.

Buckler, E.S. and Thornsberry, J.M. 2002. Plant molecular diversity and applications to genomics. Current Opinion in Plant Biology. 5:107-111.

Borém, A. 2001. Melhoramento de plantas. $3^{\text {rd }}$. UFV, Viçosa.

Borém, A. and Santos, F.R. 2002. Biotecnologia simplificada. Suprema, Visconde do Rio Branco.

Borém, A.; Santos, F.R. and Bowen, D. 2003. Understanding biotechnology. Prentice Hall, New York.

Cockerham, C.C. 1961. Implications of genetic variances in a hybrid breeding program. Crop Science. 1:47-52.

Crow, J.F. 1998. 90 Years ago: the beginning of hybrid maize. Genetics. 148:923-928.

Dobzhansky, T.H. 1937. Genetics and the Origen of Species. Columbia Univ. Press, New York.

Donald, C.M. 1968. The breeding of crop ideotypes. Euphytica. 17:385-403.

Duvick, D.N. 1996. Plant breeding: an evolutionary concept. Crop Science. 36:539-548.

Duvick, D.N. 2001. Biotechnology in the 1930s: the development of hybrid maize. Nature Reviews Genetics. 2:69.

East, E.M. 1908. Inbreeding in corn. Connecticut Agric. Exp. Stn. Rep. 1907:418-428.

East, E.M. 1909. The distinction between development and heredity in inbreeding. Am. Nat. 43:173-181.

East, E.M. and Hayes. H.K. 1912. Heterozygosis in evolution and in plant breeding. US Depart. Agr. Bur. Plant Ind. Bull. 243:1-58.

Feldman, M. 1988. Cytogenetic and molecular approaches to alien gene transfer in wheat. p.23-32. In: Proceedings of the Seventh International Wheat Genetics Symposium. Institute of Plant Science Research, Cambridge.

Flor, H.H. 1956. The complementary genic system in flax and flax rust. Adv. Genetics. 8:29-54.

Goulden, C.H. 1939. Problems in plant selection. p.132-133. In: Burnett, R.C. (Ed.) Proceedings International Genetics Congress, $7^{\text {th }}$, Edinburgh, 1939. Cambridge University Press, Edinburgh.

Harborne, J.B. 1978. Plant tissue culture and its biotechnological application. Phytochemistry. 17:16911692. 
Harlan, H.V. and Pope, M.N. 1922. The use and value of backcross in small-grain breeding. J. Hered. 13:319-322.

Hull, F.H. 1945. Recurrent selection and specific combining ability in corn. J. Am. Soc. Agron. 37:134145.

Johannsen, W. 1903. Ueber erblichkeit in populationen und in reinen linien. Gustav Fischer, Jena.

Johannsen, W. 1906. Elemente der exakten erblichkeitslehre. Gustav Fischer, Jena.

Jones, D.F. 1918. The effects of inbreeding and crossbreeding upon development. Connecticut Agric. Exp. Stn. Bull. 207:5-100.

Kasha, K.J. 1999. Biotechnology and world food supply. Genome. 42:642-645.

Kemp, M. 2002. Science in culture: peas without pictures-Gregor Mendel and the mathematical birth of modern genetics. Nature. 417:490.

Khush, G.S. 2001. Green revolution: the way forward. Nature Reviews. Genetics. 2:815-822.

Konzak, C.F; Nilan, R.A and Kleinhofs, A. 1976. Artificial mutagenesis as an aid in overcoming genetic vulnerability of crop plants. Basic Life Sciences. 8:163-177.

Koshland, D.E, Jr. 1986. The biotechnology issue. Science. 232:313.

Louwaars, R.T. 1997. Seed regulation: choices on the road to reform. Food Policy. 22:433-446.

Mackill, D.J.; Nguyen, H.T. and Zhang, J. 1999. Use of molecular markers in plant improvement programs for rainfed lowland rice. Field Crops Research. 64:177-185.

McCann, D.A and Batterham, P. 1993. Australian genetics: a brief history. Genetica. 90:81-114.

McCarty, M. 1994. A retrospective look at the discovery of the genetic role of DNA. The FASEB J. 8:889-890.

McElroy, D. 1996. The industrialization of plant transformation. Nature Biotechnology. 14:715-716.

Muller, H.J. 1927. Artificial transmutation of the gene. Science. 66:84-87.

Murashige, T. and Skoog, F. 1962. A revised medium for rapid growth and bioassays with tobacco tissue cultures. Physiol. Plant. 15:473-497.

Newman, L.H. 1912. Plant breeding in Scandinavia. Canadian Seed Grower's Association, Ottawa.
Nigel. W. 2001. When Mendel's work went public. Current Biology. 11:727.

Olsson, G. 1986. Svalof 1886-1986- research and results in plant breeding. Svalof AB Press, Svalof.

Orel, V. 1997. The spectra of inbreeding in the early investigation of heredity. History and Philosophy of the Life Sciences. 19:315-330.

Pauls K.P. 1995. Plant biotechnology for crop improvement. Biotechnology Advances. 13:673-693.

Phillips, R L. 1993. Plant genetics: out with the old, in with the new? The American Journal of Clinical Nutrition. 58:259-263.

Rasmusson, D.C. 1991. A plant breeder's experience with ideotype breeding. Field Crop Research. 26:191200.

Richey, F.D. 1927. Convergent improvement in selfed alfalfa. Am. Nat. 61:430-449.

Shull, G.H. 1908. The composition of a field of maize. Am. Breeders' Assoc. Rep. 4:296-301.

Shull, G.H. 1909. A pure line method of corn breeding. Am. Breeders' Assoc. Rep. 5:51-59.

Shull, G.H. 1910. Hybridization methods in corn breeding. Am. Breeders' Mag. 1:98-107.

Thompson, E.A. 1990. R.A. Fisher's contributions to genetical statistics. Biometrics. 46:905-914.

Tsitrone, A; Rousset, F and David, P. 2001. Heterosis, marker mutational processes and population inbreeding history. Genetics. 159:1845-1859.

Vavilov, N.I. 1951. The origin, variation, immunity and breeding of cultivated species. Translated from the Russian by K.S. Chester. Chronica Botanica. 13:1-366.

Walsh, B. 2001. Quantitative genetics in the age of genomics. Theoretical Population Biology. 59:175184.

Wright, S. 1942. Systems of mating. Genetics. 6:111178.

Xing, T. 1998. Bioinformatics and its impact on plant science. Trends in Plant Science. 3:450.

Zhang, D.Y.; Sun, G.J. and Jiang, X.H. 1999. Donald's ideotype and growth redundancy: a game theoretical analysis. Field Crops Research. 61:179-187.

Received: November 12, 2002;

Accepted: December 17, 2002. 